Journal of English Language Teaching

UNNES

\title{
Teachers' questioning strategies and students' perceptions toward critical questions in EFL classroom interaction
}

\author{
Modi Nur Kholisoh ${ }^{\bowtie}$, Dwi Anggani Linggar Bharati
}

English Department, Universitas Negeri Semarang, Indonesia

\begin{tabular}{l} 
Article Info \\
\hline Article History: \\
Received in 17 \\
December 2020 \\
Approved in 28 March \\
2021 \\
Published in 28 July \\
2021 \\
\hline Keywords: Teachers' \\
questioning strategies; \\
critical questions; students' \\
perceptions; classroom \\
interaction \\
\hline
\end{tabular}

\begin{abstract}
This study aims to find out teachers' questioning strategies and students' perceptions of critical questions in EFL classroom interaction. This research was conducted during the COVID-19 pandemic, in which the classroom interaction was online. We used a case study design that focused on the descriptive analysis. This study was conducted at one of Senior High Schools in Semarang. The participants in this study are two English teachers and two classes. The data were gained by using classroom observation, interview, questionnaire, and documentation. We used Chen's (2016) theory and Anderson \& Krathwohl (2001) to categorize and analyze the data findings to know teachers' questioning strategies and students' perceptions toward critical questions in EFL classroom interaction. The result of the analysis showed that the teachers used all of the teachers' questioning strategies and they posed critical questions. Teachers questioning strategies used by the teachers when posing critical questions were wait-time, repetition, paraphrasing, simplifying, and probing. The obvious strategy to elicit students' responses toward critical questions was probing. In line with this, the teachers also combined the teachers questioning strategies with the skill of basic questioning to elicit students' critical answers. The students didn't perceive critical question as a threat, although it was difficult to answer. However, they perceived critical question as a challenge for them. It can be concluded that the students perceived critical question as a motivational question.
\end{abstract}

Correspondence Address:

B3 Building FBS Unnes

Sekaran, Gunungpati, Semarang, 50229

E-mail: modinur29@gmail.com 


\section{INTRODUCTION}

One of the general teaching techniques of giving questions that are commonly applied in English language teaching is questioning. It is a cardinal thing for a teacher to find out the chasm between what the students have known and the development of their understanding, so the objective of the lesson will be achieved (Hall, 2006). It also involves assessment part as the on-going assessment which has several goals; they are to assess whether the students understand the material that has been taught, to engage students' participation, and to stimulate students' creative thinking in the learning process (Ennis, 1996, as cited in Ndun, 2015). It can be stated that the teacher enacts an important role in achieving the learning objectives in the classroom (Hanifah \& Bharati, 2019).

Questioning, as a part of classroom interaction, is seen as an initiative from the teachers to build a conducive atmosphere in order to activate students' interest during the teaching and learning process. It could be a stimulus to encourage and engage the students to actively engage in classroom interaction (Vebriyanto, 2015). In line with this, Yulia \& Budiharti (2019) stated that classroom interaction is seen in how teachers allow students to talk to each other with their friends and their teacher, ask or share the information they collect during the lesson. Thus, a teacher has to master teachers' questioning strategies, so he could achieve the objectives of the questioning process. By the existence of the teacher's questioning strategy, it can promote students' curiosity about the content, supply the atmosphere to the students to get new information and provide an opportunity to show their feeling and ideas related to the content (Turney et al., 1983).

Dealing with those theories about questioning, the researcher tried to connect the related theories with the factual phenomena that occur in one of the Senior High Schools in Semarang. In my observation view, the teachers have tried to build classroom interaction by questioning. While the teachers were doing the questioning, the students were quite enthusiastic to answer teachers' questions. The teachers applied two kinds of questions: lower-cognitive questions and highercognitive questions. They have developed a half portion of students' critical thinking ability toward critical questions. During the questioning section, the teachers posed several critical questions. Most of the students looked enthusiastic enough when the teachers delivered some questions related to the material being discussed. They tried to answer teachers' questions whether their answer was correct or no. Moreover, some students were quite active in posing questions when they didn't understand the material that had been discussed. Otherwise, the rest of them just tended to follow teachers' instructions without trying to pose or to answer the questions. They tended to be passive during the questioning section; even the questions were easy to answer.

A large amount of research was conducted to find out the types of questions used during the questioning section. Shomoossi (2004), in his qualitative study, showed that display questions were dominated in the classroom interaction rather than referential questions. A research aimed to know any kind of teacher's questioning strategies applied by the teachers and to find out how it impacts the students' critical thinking and students' engagement during the questioning section. Rashid \& Qaisar (2016) found that the questioning strategy had been successfully produced to promote students' critical thinking among elementary students in Pakistan. Higher-cognitive questions were successfully applied in the learning process through the questioning process. Sano (2014) revealed that questioning was well applied when the teachers asked higher-order questions more relatively frequent than the teacher in other studies. The last category explains how teachers and students perceive questioning strategies, student-teacher interaction during the questioning, and how critical thinking is perceived by both teachers and students. Ragawanti (2009) showed the findings that random nomination was more preferred than pre-arranged format nomination. Moreover, students dislike the techniques of nominating volunteering students and of giving wait time. The previous studies mostly focused on the types of question and teacher's questioning strategies applied by the teacher during the teaching and learning activity as the above researchers did. The difference between those research focuses with my focus of the study is I do not only focus on teachers' questioning strategies applied by the teacher but also I combine two focus of the study, they are teachers' questioning strategies and students' perceptions toward critical questions in EFL classroom interaction.

Question is easy to trigger thinking, ignite inquiry, and establish a dialogic relationship and it is viewed as the way to create interaction among teachers and students, assess the students to achieve the objective of the lesson (Ma, 2008). Teaching and learning cannot be separated from the questions since it is a bridge of communication that connects students' and teachers' interaction. It also helps a teacher to direct a meaningful discussion, compile students' ideas, do an on-going 
assessment, and encourage the students to be more productive in thinking (Chin, 2007). Thus, to build communication in the classroom discussion, a teacher is supposed to ask the right question. As stated by Ziyaeemehr (2016), asking the right question is the heart of effective communication and interaction during the learning process. By doing so in a particular situation can increase a whole range of communication skills. For example, we can gather better information and learn more; we can build a stronger relationship, organize people more effectively, and help others to learn too. Through consistent dialogue and communication during the learning process, the teachers can get the answer they want and evaluate students' answers at the same time.

"Skill in the art of questioning lies at the basis of all good teaching" (Betts, 1910, p. 55). The teacher requires mastering the basics of questioning during the teaching and learning process. Hence, the teachers have to know the type of questions. The question itself is classified by the level of cognitive demand to answer it. The cognitive level of questions refers Bloom's Taxonomy in which there are six levels of the cognitive level that come from the lowest to the highest. There are three types of question, they are cognitive, affective, and psychomotor. The cognitive domain includes in Revised Bloom's Taxonomy, as stated by Anderson \& Krathwohl (2001) is remember, understand, apply, analyze, evaluate, and create.

The existence of question in the learning is mostly about assessing students' understanding, whereas it serves different functions. According to Kanchak \& Eggen (1989, as cited in Ma, 2008), the functions of questions are divided into three categories: diagnostic, instructional, and motivational, but a question can have more than one function. Questioning is regarded as a beneficial and relevant medium to create classroom discussions in the classroom. As Maiza et al. (2015) stated, in order to build a good classroom discussion, teachers should have the initiative to activate students' interest. One of the best ways to form classroom discussion is questioning. Dillon (1983) prompted that questioning is one way to enhance student participation and involvement in thinking and learning. Ocbian \& Pura (2015) even argue that there will be no useful discussion during the class if the questioning is not applied. It can be stated that purposeful questioning means that the teacher encourages the students to participate in the classroom discussion by responding to questions and asking questions by themselves so they might increase their levels of understanding (Barnes et al. 1976, in Turney et al., 1983).

The implementation of questioning cannot be separated from the existence of teacher questioning strategies. There must be strategies to elicit students' responses during the questioning section. The strategies rely on sophisticated utterances that are influenced to produce critical responses made by the students. According to Chen (2016), some strategies could be implemented to get students' responses related to higher-order questions. Those strategies are wait time, repetition, paraphrasing, simplifying, and the last strategy is probing. Probing is a strategy that provides the teacher to scaffold students' thinking in order to facilitate the elicitation of students' responses.

\section{METHODS}

This research was a qualitative study that focused on descriptive analysis. It belongs to a case study that investigated teachers' questioning strategies and students' perceptions toward critical questions in EFL classroom interaction. We used the case of English teaching as the case of the study in which it was a classroom-based research project as we involved teachers and students in the classroom. In the discussion of the qualitative approach, there are several types of study. One of them is the study of document analysis. The document analysis is a study which focused on the analysis and interpretation of written, recording, and notes (Sa'adah, 2018). One of the types of study in document analysis is discourse analysis. Classroom discourse analysis was used in this study as this study was conducted in the classroom and used teachers' and students' talk as the data findings.

In this study, we chose two English teachers of Senior High School in Semarang. There were students of two classes from different grades; those are tenth and eleventh-grade students in the academic year 2019/2020 as the participants. The objects of the study are teachers' questioning strategies and students' perceptions toward critical questions in EFL classroom interaction. Here, we observed how the teachers used the questioning strategies during teaching and how the students perceived to the teachers' questioning strategies toward critical questions in the EFL classroom interaction. The question used by the teachers is based on the levels of the question of the revised Bloom's Taxonomy. They are remember, understand, apply, analyze, and create. 


\section{Data collection procedures}

To collect the data, we used some instruments. They were classroom observation, interview, questionnaire, and documentation. Classroom observation was done twice for two classes. It was done to know what the teacher and students did include what they said and what they did during the online learning activity. The next instrument we used was an interview. The aim of conducting an interview was to get the data about the implementation of teachers' questioning toward teachers' questioning strategies and strengths and weaknesses of implementing teachers' questioning toward critical questions in EFL classroom interaction. A questionnaire was a collection of data to get written data related to students' perceptions about what they perceived toward teachers' questioning strategies and their opinion about critical questions applied during the questioning section and strengths and weaknesses of questioning strategies toward critical questions in EFL classroom interaction. The last instrument was documentation. Video-recording was chosen to record the teaching and learning activity in the classroom.

\section{Data analysis}

We used transcribing, classifying, and interpreting the data to analyze the data findings. Transcribing means transcribed what the teachers and students said in the classroom activities, and also non-verbal information was noted. To classify the process, the teachers' talk, and students' talk that had been transcribed, they were classified based on the teacher questioning strategies of Chen's (2016) theory and level of questions based on Anderson \& Krathwohl's (2001) theory. The last process of analyzing is interpreting. The process of interpreting aimed to interpret the teachers' talk and students' talk. After the data findings had been classified, they were interpreted to explain the teachers' questioning strategies, what the students perceived teachers' questioning strategies and critical questions in EFL classroom interaction, and the strengths and weaknesses of implementing teachers' questioning strategies toward critical questions in EFL classroom interaction.

\section{FINDINGS AND DISCUSSION}

Based on the classroom observation, there were many teacher questioning strategies used by the teachers in each class. We classified teachers' questioning strategies into sub-main parts; those are teacher questioning strategies based on Chen (2016) and level of questions used by the teachers based on the theory of Anderson \& Krathwohl (2001) during the questioning section. According to Chen (2016), there are teacher questioning strategies; those are wait-time, repetition, paraphrasing, simplifying, and probing. Here, we explained how teacher questioning strategies worked during the teaching and learning process, and then we classified them into the table. Furthermore, we also identified the level of teacher questions by using the revised Bloom's Taxonomy (see Anderson \& Krathwohl, 2001), which includes remember, understand, apply, analyze, evaluate, and create. We categorized this section into two explanations based on the classroom observation occurred in tenth and eleventh class to know how teacher implement teacher questioning strategies toward critical questions.

\section{Teachers' questioning strategies}

As stated earlier, we classified teachers' questioning strategies based on Chen's (2016) theory, which includes wait-time, repetition, paraphrasing, simplifying, and probing. Here, we classified the findings into the table, as shown below.

Table 1. Frequency of Teacher Questioning Strategies during the Teaching and Learning Process

\begin{tabular}{ccc}
\hline Kinds of Teacher & \multicolumn{2}{c}{ Total of Strategies } \\
\cline { 2 - 3 } Questioning Strategies & Eleventh Class & Tenth Class \\
\hline Wait-time & 10 & 11 \\
\hline Repetition & 20 & 12 \\
\hline Paraphrasing & 6 & 17 \\
\hline Simplifying & 3 & 11 \\
\hline Probing & 10 & 11 \\
\hline Total & 58 & 62 \\
\hline
\end{tabular}


Here, I also analyze what level of questions used during the teaching and learning process. The analysis is based on Anderson \& Krathwohl (2001). The description of levels of question described as follow.

Table 2. Frequency of Teacher Questions Occurrence at Eleventh Class

\begin{tabular}{|c|c|c|c|c|}
\hline Cognitive Level & Levels of Questions & $\begin{array}{l}\text { Frequency of } \\
\text { Occurrence }\end{array}$ & Total of Questions & Percentage \\
\hline \multirow{2}{*}{$\begin{array}{c}\text { Low Cognitive } \\
\text { Level }\end{array}$} & Remember & Remember & \multirow{2}{*}{19} & \multirow{2}{*}{$39,58 \%$} \\
\hline & Understand & Understand & & \\
\hline \multirow{4}{*}{$\begin{array}{c}\text { High Cognitive } \\
\text { Level }\end{array}$} & Apply & Apply & \multirow{4}{*}{29} & \multirow{4}{*}{$60,42 \%$} \\
\hline & Analyze & Analyze & & \\
\hline & Evaluate & Evaluate & & \\
\hline & Create & Create & & \\
\hline Total questio & sed by the teacher & enth Class & & \\
\hline
\end{tabular}

Table 3. Frequency of Teacher Questions Occurrence at Tenth Class

\begin{tabular}{|c|c|c|c|c|}
\hline Cognitive Level & Levels of Questions & $\begin{array}{l}\text { Frequency of } \\
\text { Occurrence }\end{array}$ & Total of Questions & Percentage \\
\hline \multirow{2}{*}{$\begin{array}{c}\text { Low Cognitive } \\
\text { Level }\end{array}$} & Remember & 22 & \multirow[b]{2}{*}{34} & \multirow[b]{2}{*}{$57,62 \%$} \\
\hline & Understand & 12 & & \\
\hline \multirow{4}{*}{$\begin{array}{l}\text { High Cognitive } \\
\text { Level }\end{array}$} & Apply & 6 & \multirow{4}{*}{25} & \multirow{4}{*}{$42,38 \%$} \\
\hline & Analyze & 6 & & \\
\hline & Evaluate & 11 & & \\
\hline & Create & 2 & & \\
\hline \multicolumn{3}{|c|}{ Total questions posed by the teacher in Tenth Class } & \multicolumn{2}{|c|}{59} \\
\hline
\end{tabular}

From the result above, it can be seen that teacher A posed a high cognitive level more than a low cognitive level. Teacher A mostly posed questions in a create level of the question as it was related to the material being discussed, conditional sentence, and passive voice. In this case, she got the students to create a sentence that was still connected to the words previously. For another high cognitive level such as apply, the students had to identify the grammatical implications found in a conditional sentence and passive voice sentence. In the level of analysis question, teacher A got the students to analyze the existence of grammatical implications in a conditional sentence and passive voice sentence. Meanwhile, for the evaluative level question, the students had to evaluate which sentence was appropriate with the implementation of the conditional sentence in the form of multiple choice. It can be said that teacher A had applied critical questions in terms of analysis and evaluative questions since these questions required the students to think critically about the answer.

According to the findings above, it can be stated that teacher B gave less high cognitive level questions than low cognitive level questions. At the beginning of the questioning, teacher B posed many low cognitive questions to recall what they learned about the narrative text. Unfortunately, the students were not responsive to the teacher questions, so low cognitive questions were to engage students to participate in questioning in the EFL classroom interaction. It was an extra effort of teacher B to build tenth-grade students' engagement in the online class. However, in the middle of the questioning section, the students began to pay attention more to the reacher's question as teacher $B$ posed critical questions that belonged to high cognitive level questions, thus it made them think hard about the answer to those questions. In the form of application questions, teacher B posed questions that made the students identify the moral value of some narrative text. In analysis questions, students had to analyse why the problem arose in the narrative text. The students had to think critically when teacher B asked evaluative questions that required the students to evaluate if it was better for the narrative text to do not have a complication and to justify whether good or not a resolution in the narrative text. Another higher-level question existed to the creativity question as it required the students to imagine a character in the narrative text and expect what she would do. Therefore, it can be concluded that teacher B had applied critical questions in terms of analysis and evaluative questions. In this case, it's required for the students to think critically according to what they know combined with their perceptions. 
The use of higher-level questions such as analysis and evaluative questions had a big effect on the implementation of questioning strategies toward critical questions. In the implementation of critical questions, an analysis question is applied to determine how each part is related to each other and the overall structure (Anderson \& Krathwohl, 2001). The use of evaluative level in evaluative questions is to make a judgment based on the criteria and standards (Anderson \& Krathwohl, 2001). Here, students' perspectives also impacted the answer to the evaluative question.

\section{The implementation of teachers' questioning strategies}

I analyzed how teacher A and teacher B implemented teacher questioning strategies toward critical questions. On that day, teacher A posed several high-level questions that belong to high cognitive levels questions such as apply, analyze, evaluate, and create, but critical questions just focused on analysis and evaluative questions. The teacher questioning strategies used are based on the theory of Chen (2016); they are wait-time, repetition, paraphrasing, simplifying, and probing. The analysis of teacher questioning strategies is explained as follows.

Teacher A

Extract 4

T: Kenapa harus is being put segala?

S12: Karena verb-nya pake bentuk-ing.

T: Iya, karena verb-nya pake bentuk -ing. Verb-nya diubah jadi past participle (Verb 3) lalu pake bantuan being karena kata sebelumnya pake verb-ing. Jadi is being put.

The use of high-level questions such as analysis and evaluative questions gave a big effect on the implementation of questioning strategies toward critical questions. Students required to answer those questions as seen in the utterances "Kenapa harus is being put segala?" and "Kenapa milih yang will reduce? What is the reason?" Those questions got the students to think critically about the appropriate reason for the application of a passive voice and a conditional sentence. Kenapa, or why in this case, belongs to why questions that demanded the students to explain the reason for particular events or phenomena happens (Cole, 1994). Here, the students were demanded to explain the reason for applying "is being put" and "milih will reduce." Their higher-order thinking skill is needed to be able to answer critical questions.

Teacher B

T: Do you think it is the best way to do it?

Ss: Hmm... (Murmuring)

T: Resolution yang bagus atau tidak bagus?

Ss: Hmm... (Murmuring)

T: Resolution yang bagus atau tidak bagus?

Ss: Hmm... (Murmuring)

T: What do you think? Ran away from the house.

S15: It's not good.

S16: It's not good because she ran away.

The examples of the critical question when teacher B asked, "Do you think it is the best way to do it" and "Resolution yang bagus atau tidak bagus?" When teacher B asked those questions, actually she had implemented the questioning strategy "Probing" as it engaged in eliciting the students' response regarding the critical question (Chen, 2016). These questions made the students think about the moral value of Malin Kundang story and evaluate whether the resolution of the story entitled "Snow White" belonged to a good resolution. They belong to critical questions in the level of analyze and evaluate which include in the high level of question. In the implementation of critical questions, an analysis question was applied to determine a point of view of the story entitled "Malin Kundang." The use of evaluative questions was to make a judgment based on the criteria and standards (Anderson \& Krathwohl, 2001). This evaluative question gets the students in critique, whether ran away from home is a good resolution or no. Here, students' perspectives also impacted the answer to the evaluative question. 


\section{Students' perceptions of critical questions}

A critical question is a question that required higher-order thinking skills to answer as it digs indepth about their understanding and their belief about the material they learned previously. It's interesting to know how students perceived critical questions and their impact on their learning. I analyzed how students perceived critical questions and how it impacted their learning achievement.

Almost most students of Eleventh Class were competitive, so they agreed that critical questions should be frequently given to improve their higher-order thinking skills (75\%). Meanwhile, some of them tend to partly agree and disagree if the teacher is frequently given critical questions $(22.22 \% \& 2.78 \%)$. The reason was that not all students could answer the critical question as to the difference in students' level of thinking. The students still had difficulty responding to the critical questions. Sometimes, what they expected was not match with the teacher's expectation about the answer. Moreover, teacher A didn't explain the material in detail, so it was quite hard for the students to think deeper about the answer to critical questions. Teacher A frequently poses the critical question that did not exist in the textbook; therefore, it was also the reason for the students' difficulty to answer the critical question (63.89\%). The difficulty in interpreting the meaning of the critical questions was also the reason for being reluctant to answer a critical question. The prominent obstacle was the lack of students' English vocabulary and the lack of students' comprehension of the teacher's pronunciation.

Despite the difficulty in answering the critical question, most of the students of Eleventh Class perceived the critical question as a challenge for them (83.33\%). It challenged them to think deeper about the material they learned previously. Therefore, their enthusiasm to answer the critical question enhanced when teacher A posed the critical question (77.78\%). They competed to answer the critical question as teacher A gave them reinforcement in the form of additional points. It was useful to increase their mark when they had a bad mark on the exam. This competition made other students motivated to actively respond to the critical question. Even the students had difficulty answering critical questions using full English; they tried to answer partly in English and Bahasa Indonesia. Those students tend to use Bahasa Indonesia as they were afraid there was a miscommunication of what they answered and the teacher's expectation. Moreover, the answer did not exist in the textbook, so it was also the reason for the students' difficulty to answer the critical questions $(63.89 \%)$. The difficulty to interpret the meaning of the critical questions was also the reason to be reluctant to answer a critical question. However, they argued when they succeed in answering the critical question; they felt proud and clever as a critical question belongs to a higherlevel of question that required more effort to answer it (83.33\%).

Students of Tenth Class were less competitive than eleventh class in terms of answering teacher's questions. Therefore, some students argued teacher B should not ask critical questions frequently as it impacted their learning enthusiasm. On the contrary, they perceived a critical question as a challenge for them (58.33\%). They tend to be enthusiastic to answer the critical question when they comprehended the material well. It can be seen from the result of the questionnaire that their enthusiasm to answer the critical question reached (38.89\%). They had a lack of enthusiasm to answer the critical question, so they tend to be reluctant to answer critical questions as they had several difficulties. Some students pointed out that critical question was something hard for them to answer besides of other lower-level question. They had difficulty comprehending what teacher B meant as the lack of students' understanding of the material and the vagueness of the teacher's pronunciation when posed the critical question. Since teacher B was not clear enough to pose a critical question using English, the students feel difficult to interpret the meaning of the critical question itself. According to the classroom observation, not all students had a willingness to answer the critical question; only some of them were confident and comprehended the material being discussed. Hence, it can be said that students' confidence also impacted the willingness to answer a critical question. They were not confident enough to answer the critical question as to the lack of English proficiency because of vocabulary and grammar (44.44\%). The students can't find the critical question answer in the textbook, so it could be the reason for students' difficulty to answer critical questions (47.22\%). Moreover, they had some problem answering critical questions as it belonged to the higher-order thinking skill to answer and it needed much comprehension to do so $(66.67 \%)$.

Here, I highlighted a critical question as a challenge for the students. It means that critical question has positive impacts to their learning achievement those are guiding them to think critically; encouraging them to comprehend the material in-depth; making the conducive 
atmosphere in the EFL classroom interaction, and increasing their speaking ability. It can be stated that a critical question is perceived as a motivational question means that the question can be used effectively to involve the students in the classroom discourse that encourage and challenge them to think creatively (Kanchak \& Eggen, 1989, as cited in Ma, 2008). In other words, a critical question is not perceived as a threat to them, but it challenges them to comprehend new information related to the material being discussed. It can be concluded that the function of this question has been used effectively to involve the students in the classroom discourse. It also encourages and challenges them to think critically about the material out of the textbook.

\section{Strengths and weaknesses of implementing questioning strategies toward critical questions in efl classroom interaction}

Some considerations to state the strengths and weaknesses come from the implementation of teacher's questioning strategies conducted toward critical questions in EFL classroom interaction and the result of interpretation for other participants; those are students and me as a researcher. I combined the result of classroom observation and interview section to analyze the topic. According to the result of students' perceptions of the questioning section, they perceived a questioning section as the impact of a positive thing on the learning process. Most of the students gave positive things of the questioning section; they are one of the effective teaching strategies to create discussion in EFL classroom; improve students' English skill; enhance students' self-confidence to speak English; make the class conducive; assess students' comprehension about the material discussed; get oral responses about the material discussed; engage students' interest to the detailed concept; give an opportunity to the students to express their ideas about the material being discussed; encourage the students to participate more active during learning English, and help the students to get new knowledge out of the box.

From the result above, it can be concluded that the teachers were successfully used questioning as they could achieve the following objectives: to sharpen students' interest and attention to the detailed concept; to give the students chances to increase their ability; to make sure the students participate in the discussion forum, and to stimulate the students to be more active to ask questions; and to examine particular students' difficulties through questions that indicate where students need additional assistance (Turney et al., 1983). Hence, both teacher A and teacher B had successfully achieved the objectives of the questioning section toward critical questions in the EFL classroom interaction.

Both teachers have the point of implementing a questioning strategy toward critical questions is the use of questioning skill "Eliciting level of thought." It means that there are variations of questions during the questioning section. In other words, the teachers didn't bombard the students with critical questions, but teacher A and teacher B periodically change the level of question based on the need for the material being discussed. Stalling \& Kaskowitz (1974) in Turney et al. (1983) stated that the use of multiple levels of teacher questioning should involve both low and higher-order questions as it has a more beneficial effect on students' achievement that only focus on the frequency of higher-order questions alone.

From the statement above, it can be stated that the strengths of implementing teachers' questioning strategies toward critical questions in EFL classroom interaction are influenced by the good implementation of many factors such as effective questioning, good teacher questioning skill, and interactive interaction. Meanwhile, the weaknesses of implementing teachers' questioning strategies toward critical questions are some students sometimes still weren't used to critical questions that required them to use their higher-order thinking skill, so it diminishes their enthusiasm to answer critical questions during the questioning section. Moreover, the lack of English proficiency made them reluctant to answer critical questions. It could be another duty to conduct an activity that could enhance students' English proficiency in EFL classroom interaction; so, they are able to speak up during the questioning section.

The research was conducted in the pandemic era and classroom interaction was limited in the Zoom online meeting application. Therefore, it impacts the students' engagement during the questioning section since the meeting was online. Some students didn't get engaged in the online meeting as there was no face to face meeting in the real class. Meanwhile, other students felt enthusiastic in classroom interaction. Even the teachers acted the role properly; however, not every student paid attention to the process of online questioning. Any problems such as bad signals and bad communication tool might be the reasons they tended not to be engaged during the online 
classroom interaction in Zoom, hence it can be said that it was less interactive. The reasons for the less classroom interaction are the lack of emotional bonding among the students and the teacher and the existence of online classroom interaction. During the online classroom interaction, the interaction among students and teachers only occurred on the screen. It is really different from the real class. It also seems that they have never met the teacher offline or face to face, so the students have a lack of emotional bonding among the students themselves as well as the teachers. Those reasons might affect the lack of classroom interaction during the teaching and learning process.

\section{CONCLUSION}

In this part, I give the conclusions of the whole study that had been gained from the analysis results. Teachers' questioning strategies impacted the students' achievement to answer critical questions. It was found that the skill of questioning also influences the teachers to implement teachers questioning strategies toward critical questions. They can be combined to get students' critical responses regarding critical questions posed by the teachers. It can be seen from the findings that the teachers applied critical questions even though the students were still short.

Both teachers used all of the teachers' questioning strategies such as wait-time, repetition, paraphrasing, simplifying, and probing. Teacher A and teacher B applied low-cognitive questions that consisted of knowledge and comprehension questions. Both of them also applied high-cognitive questions that belonged to critical questions such as analyze and evaluate. The teacher questioning strategies are influenced by the implementation of teacher questioning strategies "Probing" toward critical questions.

There are two main perceptions of critical questions that impacted students' learning. The students perceived a critical question as a challenge for them. It challenged them to think critically about the material being learned. Second, a critical question is perceived as a difficult question to be answered. However, they didn't perceive a critical question as a 'threat' for them. It can be concluded that the strengths of implementing teachers' questioning strategies toward critical questions are to help the students to achieve the learning objectives regarded to the higher-order thinking skills; to make the students have a better understanding of the material being discussed; to help the students understand deeply about the material delivered by the teacher; to improve students' critical thinking skill, and to challenge the students to solve the problem critically and creatively. The good implementation is influenced by the good implementation of the questioning section, the good implementation of teacher questioning strategies combined with the good skill of questioning, and the interactive atmosphere interaction in the EFL class. The weaknesses of the implementation of teacher's questioning strategies toward critical questions are some students still weren't used to critical questions as it required them to use higher-order thinking skill to answer, so it diminishes their enthusiasm to answer critical questions during the questioning section. In line with this, the weaknesses of implementing teacher's questioning strategies also influenced by the lack of students' English proficiency and lack of comprehension of the material discussed. Even though teacher questioning strategies were implemented well, some teachers' questioning strategies and teachers' questioning skills should be improved to get a better implementation of teachers' questioning strategies toward critical questions in EFL classroom interaction.

The first suggestion is for English teachers. In implementing teachers' questioning strategies, a teacher should engage the students to participate in the questioning section. The teacher also has to pose either a lower or higher-level of questions during the learning process. To enhance students' critical thinking skills, it is suggested to apply a higher-level of questions, especially critical questions. Probing is a strategy to elicit students' responses by giving probing questions. The use of probing question is to explore further information related to the critical questions given. As the importance of probing questions, it is suggested that probing questions should be improved well, so it would make the students answer to a critical questions. Other questioning strategies also should be improved, such as wait-time, repetition, paraphrasing, and simplifying. Each strategy cannot be stood alone; hence, it would get better to combine all of those strategies to make the questioning section responsive and attractive.

Second, students should be more active in answering the question, especially critical questions, without being reluctant and not confident. The teacher could provoke the students with a lower-level of questions before posing a higher-level of the question, in this case, is a critical question. If the students want to improve their self-confidence, they could answer the teacher's 
questions periodically. Another thing that could be implemented to stimulate the students to actively answer the critical question is by the use of token reinforcement to which give additional score; thus, they will be motivated to answer the question.

Third is suggestion for future researchers. This study contains a reference to conduct the research related to teachers' questioning strategies and students' perceptions toward critical questions. From this study, they will get the theory about the implementation of teachers' questioning strategies and how the students perceived critical questions in EFL classroom interaction. This study provides students' perceptions when they are given critical questions in which can be used to support theory and evidence for their research. I suggest to future researchers to explore widely students perceptions toward other types of questions, for example, students' perceptions toward factual questions.

\section{REFERENCES}

Anderson, L. W., \& Krathwohl, D. R. (2001). A Taxonomy for Learning, Teaching and Assessing: A Revision of Bloom's Taxonomy. New York: Longman Publishing.

Betts, G. H. (1910). The Recitation. Washington: Houghton-Mifflin.

Chen, M. (2016). Theoretical Framework for Integrating Higher-order Thinking into L2 Speaking. 6(2), $217-$ 226.

Chin, C. (2007). Teacher Questioning in Classrooms: Approaches that Stimulate Productive Thinking. Journal of Teacher in Science Teaching Vol 4 (6) 814-843.

Cole, P. P. (1994). Teaching Principles and Practice (2 ${ }^{\text {nd }}$ Edition). Australia: Prentice Hall of Australia Pty Ltd.

Dillon, J. T. (1983). The Use of Questions in Educational Research. 9 (12) 19-24. University of California, Riverside.

Hall, J. W. (2006). New Handbook for Auditory Evoked Responses. Texas: Pearson.

Hanifah, F. M., \& Bharati, D. A. L. (2019). Journal of English Language Teaching The Comparison between Wattpad and Blog in Project-Based Learning to. 8(1), 109-119.

Kanchak, D., \& Eggen, P. D. (1989). Learning and Teaching. Mass: Allyn and Bacon, pp. 24-56.

$\mathrm{Ma}, \mathrm{X}$. (2008). The Skills of Teacher's Questioning in English Classes. International Education Studies, 1(4), 92-100. https://doi.org/10.5539/ies.v1n4p92.

Maiza, M., Rukmini, D., \& Sofwan, A. (2015). Teachers' Basic Questionings Used By English Teachers In Teaching English. English Education Journal 5(1), 1-7.

Ndun, L. N. (2015). Teacher Question in the Junior High School English Classroom. Thesis. Sanata Dharma University, Yogyakarta, Indonesia.

Ocbian, M. M., \& Pura, J. E. (2015). Questioning Strategies of Literature Teachers among Grade 8 Filipino Students. 3(4), 42-51.

Ragawanti, T. D. (2009). Questions and Questioning Techniques: A View of Indonesian Students' Preferences. StiBA Satya Wacana 2 (11) 155-170.

Rashid, S., \& Qaisar, S. (2016). Developing Critical Thinking through Questioning Strategy among Fourth Grade Students. 38(2) Bulletin of Education and Research, 153-168.

Sa'adah, K. (2018). The Teachers' Questions to Encourage Students' Critical Thinking. Final Project. Semarang State University.

Sano, M. (2014). Critical Thinking and Teachers' Questioning Behavior in a Japanese University EFL Context.Thesis. Soka University, Japan.

Shomoossi, N. (2004). The Effects of Teachers' Questioning Behaviour on EFL Classroom Interaction: A Classroom Research Study. The Reading Matrix, 4(2), 96-104.

Turney, C., Eltis, K.J., Hatton, N., Owens, L.C., Towler L.C., \& Wright, R.. (1983). Sydney Micro Skills Redeveloped. London: Sydney University Press.

Vebriyanto, D. A. (2015). Teacher's Questions in EFL Classroom Interaction. Vision: Journal for Language and Foreign Language Learning, 4(2), 279. https://doi.org/10.21580/vjv4i21595.

Yulia, Y., \& Budiharti, F. R. (2019). HOTS in Teacher Classroom Interaction : A Case Study. Journal of English Education, Literature, and Culture 2 (4), 132-141.

Ziyaeemehr, A. (2016). Use of Questioning Techniques and the Cognitive Thinking Processes Involved in Student-Lecturer Interactions. International Journal of Humanities and Cultural Studies, 3(1), 1427-1442. 